\title{
Pengaruh Motivasi Belajar terhadap Prestasi Belajar Siswa pada Mata Pelajaran Ekonomi Bisnis di Sekolah Menengah Kejuruan Muhammadiyah 2 Pekanbaru
}

\author{
The Influence of Students' Learning Motivation toward Their Learning Achievement on \\ Business Economics Subject at Vocational High School of Muhammadiyah 2 Pekanbaru
}

\author{
Salmiah $^{*)}$ Yulia Novita**) Novia Rahmawita***) \\ Email: nofiarahmawita@gmail.com \\ Jurusan Pendidikan Ekonomi, Fakultas Tarbiah dan Keguruan Universitas Islam Negri Sultan Syarif \\ Kasim Riau, Pekanbaru, \\ *)yulia.novita@uin-suska.ac.id \\ **) salmiah@uin-suska.ac.id \\ ***)nofiarahmawita@gmail.com
}

\begin{abstract}
This research aimed at knowing the influence of students' extrinsic learning motivation toward their learning achievement on Business Economics subject at Vocational High School of Muhammadiyah 2 Pekanbaru. This research was instigated by students who could not reach the minimum standard of passing grade, so their learning achievement was not yet maximum. It was a quantitative research. The subjects of this research were the eleventh-grade students of Accounting 1 and 2 and Marketing. Questionnaire and documentation were the techniques of collecting data. The technique of analyzing the data was simple linear regression test. Based on the research findings, it could be concluded that there was a significant influence of students' extrinsic learning motivation toward their learning achievement on Business Economics subject at Vocational High School of Muhammadiyah 2 Pekanbaru. It was proven by the comparison between $r_{\text {observed }}$ and $r_{\text {tabel }}$, it was obtained that $r_{\text {observed }}$ was higher than $r_{\text {tabel }}$ at $5 \%$ and $1 \%$ errors $(0.202<0.664>0.263)$, so $H_{0}$ was rejected and $H_{a}$ was accepted. The contribution of the influence of students' extrinsic learning motivation toward their learning achievement was $44.1 \%$, and the rest $(100 \%-44.1 \%=55.9 \%)$ was influenced by other factors that were not discussed in this research.
\end{abstract}

Keywords: Effect, Influence, Learning Motivation, Learning Achievement

\begin{abstract}
Abstrak
Penelitian ini bertujuan untuk mengetahui besarnya pengaruh motivasi belajar ekstrinsik terhadap prestasi belajar siswa pada mata pelajaran ekonomi bisnis di Sekolah Menengah Kejuruan Muhammadiyah 2 Pekanbaru. Penelitian ini dilatar belakangi oleh masih ada siswa yang belum mencapai nilai kriteria ketuntasan minimal sehingga prestasi belajarnya masih kurang maksimal. Penelitian ini adalah penelitian deskriptif korelatif dengan pendekatan kuantitatif. Subjek dalam penelitian ini adalah kelas XI Akuntansi 1, Akuntansi 2, dan Pemasaran. Objek dalam penelitian ini yaitu motivasi belajar ekstrinsik dan prestasi belajar Teknik pengumpulan data dalam penelitian ini menggunakan angket dan dokumentasi. Teknik analisis data yang digunakan adalah uji regresi linear sederhana. Dari analisis data diketahui pengaruh yang signifikan antara motivasi belajar ekstrinsik terhadap prestasi belajar siswa di SMK Muhammadiyah 2 Pekanbaru. Hasil ini terbukti dari perbandingan $r_{\text {hitung }}$ dengan $r_{\text {tabel }}$ didapati bahwa $r_{\text {hitung }}$ lebih besar dari $r_{\text {tabel }}$ baik untuk kesalahan 5\% maupun $1 \%(0,202<0,664>0,263)$, maka $H_{0}$ ditolak dan $H_{a}$ diterima. Kontribusi pengaruh motivasi belajar ekstrinsik terhadap prestasi belajar siswa sebesar $44,1 \%$ sedangkan siswanya $(100 \%-44,1 \%=55,9 \%)$ dipengaruhi oleh faktor lain yang tidak dibahasa dalam penelitian ini.
\end{abstract}

Kata kunci: Pengaruh, Motivasi Belajar, Prestasi Belajar 


\section{PENDAHULUAN}

Pendidikan selalu mendapat perhatian khusus dari seluruh bangsa yang ada di dunia. Pasalnya melalui pendidikan suatu negara dapat mengembangkan potensi negaranya. Pendidikan merupakan salah satu upaya yang dilakukan negara untuk meningkatkan sumber daya manusia. Pendidikan yang berkualitas akan menghasilkan generasi yang berkualitas pula.

Setiap individu yang melalui jenjang pendidikan akan mengalami proses belajar dan pembelajaran. Proses belajar akan menuntun individu untuk dapat mengetahui apa yang belum mereka ketahui, pengalaman-pengalaman baru melalui interaksi sehingga terciptanya perubahan tingkah laku pada setiap individu. Sebagaimana menurut Rusman, belajar dapat diartikan sebagai suatu proses yang dilakukan oleh individu untuk memperoleh perubahan tingkah laku baru secara keseluruhan, sebagai hasil dari pengalaman individu itu sendiri dalam berinteraksi dengan lingkungannya (Rusman, 2013).

Perubahan tingkah laku merupakan hasil dari suatu proses belajar. Hal ini dipengaruhi oleh beberapa faktor. Menurut Slameto \& Suryabrata dalam Hadis \& Nurhayati (2014), terdapat dua faktor utama yang mempengaruhi belajar, yaitu faktor yang bersumber dari dalam peserta didik (internal) dan faktor yang bersumber dari luar peserta didik (eksternal). Faktor internal misalnya faktor jasmaniah seperti kesehatan dan cacat tubuh, faktor kelelahan seperti peserta didik mengalami gangguan kesehatan sehingga tidak dapat belajar secara optimal dan faktor psikologis seperti intelejensi, minat, perhatian, bakat, motivasi, kematangan dan kesiapan.Sedangkan faktor eksternal merupakan faktor lingkungan keluarga, sekolah dan masyarakat.

Berdasarkan faktor-faktor tersebut motivasi merupakan salah satu hal yang mempengaruhi belajar. Motivasi merupakan dorongan yang ada pada diri sesorang untuk melakukan tindakan. Dalam belajar siswa akan melakukan perbuatan belajar untuk memperoleh pengetahuan, keterampilan dan sebagainya dengan adanya motivasi. Motivasi belajar yang dapat tumbuh dari dalam diri sendiri disebut dengan motivasi intrinsik, sementara motivasi belajar yang timbul berkat dorongan dari luar seperti pemberian angka, kerja kelompok, hadiah atau teguran disebut dengan motivasi belajar ekstrinsik (Hamalik, 2012).

Motivasi intrinsik merupakan motivasi yang paling diharapkan dapat mendorong aktivitas belajar siswa, karena menjadi pertanda bahwa siswa memiliki kesadaran dalam dirinya untuk mencapai tujuan belajarnya dengan baik. Namun bukan berarti kedudukan motivasi belajar ekstrinsik menjadi tidak penting, sebagaimana yang disampaikan Amna Emda (2017), Motivasi Intrinsik sulit diciptakan karena motivasi ini datangnya dari dalam diri siswa hal yang mungkin dapat dilakukan adalah dengan mengembangkan motivasi ekstrinsik untuk menambah dorongan kepada siswa agar lebih giat belajar.

Dalam Al-Qur'an Allah juga menjelaskan tentang pentingnya motivasi dalam belajar, yaitu pada surah AlMujadilah Ayat 11 (Wahab, 2018): 


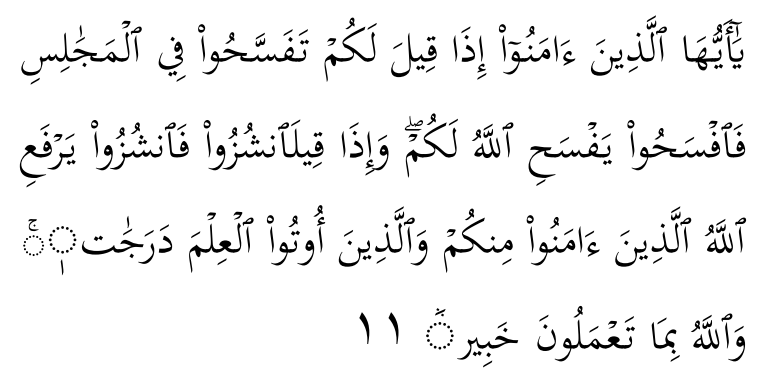

Artinya : Hai orang-orang yang beriman, apabila dikatakan kepadamu : 'Berlapanglapanglah dalam majlis', maka lapangkanlah. Niscaya Allah akan memberi kelapangan untukmu. Dan apabila dikatakan : 'Berdirilah kamu', maka berdirilah, niscaya Allah akan meninggikan orang-orang yang beriman di antaramu dan orang-orang yang diberi ilmu pengetahuan beberapa derajat. Dan Allah maha mengetahui apa yang kamu kerjakan."

Sebagaimana yang dijelaskan dalam surah Al Mujadilah ayat 11, bahwa Allah memerintahkan umat muslim untuk menuntut ilmu, baik ilmu tentang dunia maupun tentang akhirat. Selan itu, Allah juga menyerukan untuk memberikan kemudahan bagi orang lain dalam menunut ilmu, dengan begitu Allah juga akan memberikan kita kemudahan dalam menuntur ilmu. Allah akan menaikkan derajat orang-orang yang beriman dan berilmu serta Allah maha mengetahui setiap apapun yang dikerjakan hamba-Nya. Dari sini dapat kita lihat bahwa Allah telah memberikan motivasi kepada umat-Nya untuk menuntut ilmu dengan menaikkan derajat orang-orang yang beriman dan berilmu.

Berdasarkan uraian motivasi di atas, dapat dipahami bahwa motivasi yang baik akan mendorong siswa untuk belajar lebih baik dan efektif. Oleh sebab itu motivasi merupakan salah satu hal penting dalam tercapainya keberhasilan belajar. Siswa yang memiliki motivasi yang baik akan memiliki prestasi yang baik pula.

Prestasi belajar merupakan hasil yang diperoleh karena aktivitas belajar yang dilakukan seseorang. Prestasi belajar menunjukkan kemajuan yang dialami siswa dalam segala hal yang dipelajari siswa di sekolah yang menyangkut pengetahuan atau keterampilan. Sebagaimana menurut Zaiful Rosyid, dkk (2019) prestasi belajar merupakan hasil dari suatu proses pembelajaran disertai dengan perubahan yang dicapai seorang siswa dan dinyatakan dalam bentuk symbol, angka, huruf maupun kalimat sebagai ukuran keberhasilan yang dicapainya berdasarkan standard yang telah ditetapkan.

Berdasarkan penelitian awal yang penulis lakukan, penulis melihat bahwa dalam proses pembelajaran banyak siswa yang bercerita dan keluar masuk saat guru sedang menjelaskan. Berdasarkan informasi dari guru bidang studi diketahui bahwa banyak siswa yang sulit mencapai kriteria ketuntasan minimal dalam nilai ulangan dan ujiannya. Selain itu penulis juga melihat bahwa guru sudah melakukan upaya dalam memotivasi siswa untuk belajar, seperti memberikan penghargaan secara verbal, menggunakan variasi metode pengajaran serta menyelingi pembelajaran dengan punishment dan reward untuk meningkatkan semangat belajar siswa.

Berdasarkan studi pendahuluan yang penulis lakukan, penulis menemukan bahwa masih terdapat gejala-gejala sebagai berikut: 1) Masih ada siswa yang belum mencapai nilai kriteria ketuntasan minimal (KKM); 2) Masih ada siswa yang belum menyelesaikan tugas yang diberikan gurunya; 3) Masih ada siswa yang kurang memperhatikan penjelasan guru; dan 4) 
Masih ada siswa yang kurang merespon saat pembelajaran.

\section{METODE}

Jenis penelitian pada penelitian ini adalah penelitian kuantitatif. Penelitian kuantitaif adalah penelitian yang berlandasarkan pada filsafat positivism, digunakan untuk meneliti pada populasi atau sampel tertentu. Teknik pengambilan data menggunakan instrumen penelitian. Analisis data bersifat kuantitatif/statistic dengan tujuan untuk menguji hipotesis yang telah ditetapkan Rosyid, dkk (2019) Instrumen yang digunakan adalah angket.

\section{HASIL DAN PEMBAHASAN}

Analisis data yang dilakukan untuk menguji hipotesis dalam penelitian ini dilakukan dengan regresi linear sederhana. Penyajian data berdasarkan angket yang diberikan kepada siswa kelas XI Jurusan Akuntansi dan Perbankan Syariah di SMK Muhammadiyah 1 Pekanbaru berisi 31 pernyataan dengan responden berjumlah 94 siswa. Berdasarkan tabel rekapitulasi data dari variable motivasi ekstrinsik, maka diperoleh data sebagai berikut : "Sangat Setuju" sebanyak 820, "Setuju" sebanyak 1592, "Ragu-ragu" sebanyak 362, "Tidak Setuju" sebanyak 132 dan "Sangat Tidak Setuj”" sebanyak 8. Selanjutnya setelah angka persentasi dihitung maka diperoleh hasilnya yaitu $81,17 \%$. Hal ini menunjukkan bahwa motivasi belajar ekstrinsik siswa di SMK Muhammadiyah 2 Pekanbaru dikategorikan sangat baik karena berada pada rentang $81 \%-100 \%$.

Selanjutnya data prestasi belajar siswa dilihat dari nilai Ujian Akhir Semesternya. Jumlah data penelitian sebesar 94 dengan skor yang diproleh 7883.
Berdasarkan data tersebut maka besarnya persentasi hasil penelitian adalah sebesar 83,86 . Hasil tersebut menunjukkan bahwa prestasi belajar siswa di SMK Muhammadiyah 2 Pekanbaru tergolong baik, karena memiliki rata-rata 83,86 yang mana lebih tinggi dari KKM yang ditetapkan sekolah.

Berdasarkan analisis data bahwa motivasi belajar ekstrinsik memiliki pengaruh yang signifikan terhadap prestasi belajar siswa pada mata pelajaran ekonomi di SMK Muhammadiyah 2 Pekanbaru yang terbukti dari nilai $r$ hitung $>r$ tabel baik pada taraf signifian $5 \%$ maupun $1 \%$ atau $(0,202<0,664>0,263)$ ini berarti $\mathrm{Ha}$ ditolak, Ho diterima. Persentase sumbangan pengaruh variabel independen terhadap variabel dependen sebesar $44,1 \%$ atau variasi variabel independen yang digunakan dalam model (motivasi belajar ekstrinsik) mampu menjelaskan sebesar 44,1\% variabel dependen (prestasi belajar siswa), sedangkan sisanya sebesar 55,9\% (100\%$44,1 \%$ ) dipengaruhi oleh variabel lain yang tidak dimasukkan dalam penelitian ini.

Hasil penelitian didukung oleh teori yang dikemukakan oleh Susanto (2013) mengkategorikan faktor-faktor yang mempengaruhi prestasi belajar kedalam dua kelompok, yaitu faktor internal dan faktor eksternal yang mana di dalamnya terdapat salah satunya yaitu motivasi. Motivasi terbagi dari dua macam yaitu: motivasi inrinsik (dalam diri siswa) dan motivasi belajar ekstrinsik (luar diri siswa).

Selanjutnya penelitian ini juga didukung oleh teori yang dikemukakan oleh Aini (2016) bahwa semakin tinggi motivasi belajar siswa, baik itu secara intrinsic maupun ekstrinsik, maka akan sebaik pula perolehan hasil belajarnya. Namun sebaliknya, apabila motivasi belajar siswa 
rendah maka siswa akan mendapatkan kesulitan untuk mencapai hasil belajar yang baik.

Berdasarkan hasil dari analisis data dan teori yang telah dikemukakan, maka dapat disimpulkan bahwa dalam proses belajar dan mengajar kehadiran motivasi sangat mempengaruhi prestasi belajar siswa. Motivasi belajar baik secara intrinsik maupun ekstrinsik sangat menentukan keberhasilan siswa dalam pembelajaran. Oleh sebab itu pemberian motivasi secara ekstrinsik harus lebih giat dilakukan oleh guru ataupun orang tua siswa.

Hasil dari penelitian ini sejalan dengan penelitian yang dilakukan oleh Asri Wigati dan Ady Soejoto, yang mana dalam penelitian tersebut diperoleh hasil bahwa motivasi belajar ekstrinsik berpengaruh positif dan signifikan terhadap hasil belajar siswa. Hal ini berarti apabila motivasi belajar ekstrinsik siswa tinggi maka hasil belajar yang dicapai juga akan tinggi (Wigati \& Sojoto, 2018).

Namun hasil dari penelitian ini berbanding terbalik dengan penelitian yang dilakukan oleh Aini (2016), yang mana dalam penelitian tersebut di dapatkan hasil bahwa pengaruh motivasi belajar ekstrinsik terhadap prestasi belajar siswa tidak signifikan. Terjadi perbedaan antara penelitian yang penulis lakukan dan Qurratul Aini mungkin disebabkan oleh kondisi subjek penelitian yang berbeda.

Kondisi ini membuktikan bahwa tingkat motivasi eksternal dapat mengoptimalkan pencapaian tujuan pembelajaran, karena adanya dorongan yang berasal dari luar diri siswa, misalnya kegiatan pembelajaran yang kondisif dan aktivitias pembelajaran yang diikuti siswa selama proses pembelajaran yang nyaman dapat memberikan semangat yang tinggi bagi siswa dalam mengiktui pembelajaran dengan baik.

Pemberian motivasi ekstrinsik yang semakin baik dan sering lama kelamaan akan membentuk motivasi intrinsik yaitu motivasi yang datang dari dalam diri siswa itu sendiri. Motivasi intrinsik ini merupakan motivasi yang paling baik, namun karena sulit muncul di dalam diri seseorang maka pemberian motivasi ekstrinsik akan berperan penting sehingga siswa dapat memiliki motivasi dan semangat belajar yang baik, hasil dan tujuan pembelajaran pun dapat dicapai dengan optimal.

\section{KESIMPULAN}

Berdasarkan hasil penelitian dan analisis data, maka penulis dapat mengambil kesimpulan bahwa, terdapat pengaruh yang signifikan antara motivsi belajar ekstrinsik terhadap prestasi belajar siswa pada mata pelajaran ekonomi di SMK Muhammadiyah 2 Pekanbaru yang terbukti dari nilai $r$ hitung $>r$ tabel baik pada taraf signifian 5\% maupun $1 \%$ atau $(0,202<$ 0,664 > 0,263) ini berarti Ha ditolak, Ho diterima. Persentase sumbangan pengaruh motivasi belajar ekstrinsik terhadap prestasi belajar siswa $44,1 \%$ sedangkan sisanya dipengaruhi oleh variabel lain yang tidak dimasukkan dalam penelitian ini

\section{DAFTAR PUSTAKA}

Aggraeni, S. R. (2014). Faktor-faktor yang Mempengaruhi Prestasi Belajar Mahasiswa Program Studi Akuntansi. Jurnal Akuntansi dan Keuangan, Vol. 3 No. 2 .

Aini, Q. (2016). Pengaruh Motivasi Belajar Intrinsik dan Ekstrinsik Terhadap Prestasi Belajar Ekonomi Di SMA NW Pancor Lombok Timur NTB. Jurnal Gane Swara, Vol. 1 No. 2. 
Ali, M. (2014). Guru dalam Proses Belajar Mengajar. Bandung: Sinar Baru Algensindo.

Arikunto, S. (2011). Prosedur Penelitian Suatu Pendekatan Praktis. Jakarta: Rineka Cipta.

Aunurrahman. (2013). Belajar dan Pembelajaran. Bandung: Alfabeta.

Aziz, A.L. (2017). Pengaruh Motivasi Belajar Intrinsik dan Motivasi Ekstrinsik Terhadap Prestasi Belajar Siswa Pada Mata Pelajaran Ekonomi Bisnis, Skripsi. Jurusan Pendidikan IPS, Universitas Negeri Makassar, Makassar

Daryanto. (2010). Belajar Mengajar. Bandung: CV. Yarma Widya.

Djamari, S. B. (2011). Psikologi Belajar. Jakarta: Rineka Cipta.

Firdianti, A. (2018). Implementasi Manajemen Berbasis Sekolah Dalam Meningkatkan Prestasi Belajar Siswa. Yogyakarta: Gre Publishing.

Halimah, N. (2011). Pengaruh Motivasi Belajar dan Fasilitas Belajar Terhadap Prestasi Belajar Mata Pelajaran Kompetensi Kejuruan Administrasi Perkantoran. Skripsi. Jurusan Pendidikan Ekonomi, Universitas Negeri Semarang. Semarang

Hamalik, O. (2012). Pendekatan Baru Strategi Belajar Mengajar Berdasarkan CBSA. Bandung: Sinar Baru Algasindo.

Hartono. (2011). Statistik Untuk Penelitian. Yogyakarta: Pustaka Pelajar.

Husamah, etall. (2018). Belajar dan Pembelajaran. Malang: Universitas Muhammadiyah Malang.

Irianto, A. (2013). Pendidikan Sebagai Investasi Dalam Pemabangunan Suatu Bangsa. Jakarta: Kencana.

Ismail, F. (2018). Statistika Untuk Penelitian Pendidikan dan Ilmu-ilmu Sosial. Jakarta: Prenadamedia Group.

Kadir. (2018). Statistik Terapan. Depok: PT. Rajagrafindo.
Mudjiono \& Dimiyati. (2013). Belajar dan Pembelajaran. Jakarta: PT. Rineka Cipta.

Muhibbinsyah, (2010). Psikologi Pendidikan. Bandung: Remaja Rosdakarya. (2011). Psikologi Belajar. Bandung: Remaja Rosdakarya.

Mularsih \& Karwono. (2017). Belajar dan Pembelajaran. Depok: PT. Rajagrafindo.

Nurhayati, A. H. (2014). Psikologi Dalam Pendidikan. Bandung: Alfabeta.

Pratiwi, N. K. (2015). Pengaruh Tingkat Pendidikan Perhatian Orang Tua dan Minat Belajar Siswa Terhadap Prestasi Belajar Bahasa Indonesia Siswa SMK Kesehatan di Kota Tangerang. Jurnal Pujangga, Vol. 11 No. h. 8.

Prayitno, D. (2016). SPSS Handbook. Yogyakarta: Mediakom.

Purwanto, N. (2011). Psikologi Pendidikan. Bandung: PT. Remaja Rosdakarya.

Riduwan. (2011). Skala Pengukuran Variabel-Variabel Penelitian. Bandung: Alfabeta.

Rusman. (2012). Model-model Pembelajaran Mengembangkan Profesionalisme Guru. Jakarta: Rajagrafindo. (2012). Belajar dan Pembelajaran Berbasis Teknologi Informasi dan Komunikasi. Depok: PT. Rajagrafindo Persada (2013). Belajar dan Pembelajaran Berbasis Komputer. Alfabeta: Bandung..

Sardiman. (2011). Interaksi \& Motivasi Belajar Mengajar. Jakarta: PT. Rajagrafindo.

Siregar, S. (2013). Metode Penelitian Kuantitatif Dilengkapi Dengan Perbandingan Perhitungan Manual \& SPSS. Prenada Media Group.

Soemanto, W. (2012). Psikologi Pendidikan. Jakarta: PT. Rineka Cipta. 
Suarni. (2017). Meningkatkan Keaktifan Belajara Siswa Pada Kompetensi Organisasi Pelajaran PKN Melalui Pendekatan Pembelajaran Pakem Untuk Kelas IV SD Negeri 06498 Medan Johor T.A 2014/2015. 1.

Sudjana, N. (2017). Penilaian Hasil Proses Belajar Mengajar. Bandung: PT. Remaja Rosdakarya.

Sudjiono, A. (2010). Pengantar Statisk Pendidikan. Jakarta: Rajawali Pers.

Sugiyono. (2015). Metode Penelitian Pendidikan. Bandung: Alfabeta.

Susanto, A. (2013). Teori Belajar \& Pembelajaran Di Sekolah Dasar. Jakarta: Kencana.

Wahab, R. (2018). Psikologi Belajar. Jakarta: Rajagrafindo.

Wibowo, N. (2016). Upaya Peningkatan Keaktifan Siswa Melalui Pembelajaran Berdasarkan Gaya Belajar Di SMK Negeri 1 Septosari. 1.

Yamin, M. (2010). Kiat Membelajarkan Siswa. Jakarta: Gaung Persada Perss Jakarta. 